Original Article

\title{
AWARENESS ON CERVICAL CANCER-RISK ASSESSMENT
}

\author{
B. DIVYA JYOTHI*, S. BHAVYA SAI, B. CHAITANYA LAKSHMI, S. K. SHAFIYA BEGUM ${ }^{1}$, A. SATISH KUMAR ${ }^{2}$ \\ ${ }^{1}$ Department of Pharmacy Practice, Chalapathi Institute of Pharmaceutical Sciences, Lam, Guntur, Andhra Pradesh, ${ }^{2}$ Department of \\ Oncology, Govt. General Hospital, Guntur \\ Email: divyajyothibulla14@gmail.com
}

Received: 04 Apr 2017 Revised and Accepted: 21 Dec 2017

\begin{abstract}
Objective: To create awareness on cervical cancer, a level of knowledge about cervical cancer, to be advised of effective screening procedures based on their risk assessment, to educate about preventive measures after screening.

Methods: This is a prospective questionnaire-based survey conducted by providing materials such as patient information leaflets, video clips and posters and educating the public regarding the disease from $1^{\text {st }}$ January 2016-30 ${ }^{\text {th }}$ June 2016 i.e. for a period of 6 mo.

Results: Knowledge was provided by using pictures, presentations, and patient information leaflets. Out of 1000 population, the respondents 762 (76.2\%) females and 200 (20\%) males were aware of cervical cancer. Among the 48 women who attended the screening, 23(47.9\%) were identified with various symptoms and are on treatment. Out of these, 3 members were diagnosed positively and level of knowledge has increased significantly
\end{abstract} after creating awareness.

Conclusion: Primarily health care professionals such as nurses and pharmacists should also be educated in various aspects to upgrade their knowledge as it was observed that their level of knowledge was relatively low. Clinical pharmacist in this regard has a major role to play in up lifting and improving the quality of life of the patient.

Keywords: Cervical cancer, Knowledge, Screening, Awareness

(C) 2018 The Authors. Published by Innovare Academic Sciences Pvt Ltd. This is an open access article under the CC BY license (http://creativecommons.org/licenses/by/4.0/) DOI: http://dx.doi.org/10.22159/ijpps.2018v10i2.18882

\section{INTRODUCTION}

Cervical cancer is the second most common cancer in women worldwide, with over $90 \%$ of cases occurring in developing countries. Most of the cases and deaths are seen in developing countries and India attributes to about $15 \%$ of the cancer deaths in the world mostly in rural areas. A persistent infection with a highrisk oncogenic human papillomavirus (HR-HPV) is involved in almost all cases [1]. HPV infection is very common in young women with early sexual activity, with a peak before $25 \mathrm{y}$, usually without clinical consequence. In nearly $10 \%$ of cases, this infection persists and is associated after 5 to $10 \mathrm{y}$ with lesions that may regress, remain stable or progress to a higher grade and invasive cancer. Evolution of cervical intraepithelial neoplasia (CIN) to invasive cancer is slow, about 10 to $20 \mathrm{y}$ for an immunocompetent woman. This slow progression allows an effective secondary prevention based on screening and treatment of precancerous lesions, using cervical cytological testing according to Papanicolaou (Pap smear or Pap test), visual inspection of the cervix with $3-5 \%$ acetic acid (VIA), or more recently HPV DNA testing. Immuno-suppression, especially due to human immunodeficiency virus (HIV) infection, is a predisposing factor for persistent infection with HR-HPV and the development of squamous intraepithelial lesions (SIL). High HIV viral loads and low CD4 counts are associated with a higher risk of HR-HPV infection and cervical abnormalities. The risk of recurrence or progression of cervical lesions is 4-5 times higher in women living with HIV. Infection with one of the 15 HR-HPV genotypes is significantly more common in HIV-infected women, while the distribution of low-risk oncogenic HPV is not affected by HIV status $[2,3]$. This reflects a higher propensity of HR-HPV in determining persistent infections. A vaccine called Gardasil has been developed that protects against the two high-risk HPV types (types 16 and 18), which cause $70 \%$ of cervical cancers in women and $90 \%$ of all HPVrelated cancers in men five. It also protects against two low-risk HPV types (types 6 and 11), which cause $90 \%$ of genital warts. Gardasil is used in the school-based national HPV vaccination program. Another vaccine called Cervarix is available, which protects against the same two high-risk HPV types (types 16 and 18). It does not protect against low-risk HPV types which cause genital warts. Over 187 million doses of Gardasil have been given safely, in over 130 countries around the world [4].

\section{MATERIALS AND METHODS}

A community-based Prospective self-questionnaire survey to create awareness among the public about cervical cancer and, advice for effective screening, lifestyle modifications, prevention among the public was conducted for a period of 6 mo from January to June in Guntur.

\section{Materials}

Consent form, Data collection form-I, Data collection form-II, Awareness aids-Patient information leaflets, Posters, Multimedia, Questionnaire forms-I and II, Risk assessment questionnaire, Feedback form.

\section{Inclusion criteria}

All men and women aged above 14yrs for awareness.

\section{Exclusion criteria}

Women with total hysterectomy.

Women with a positive history of cervical cancer.

\section{Plan of work}

The work was planned to carry out accordingly as follows.

To include people satisfying the criteria, we had designed a patient data collection form and a questionnaire form to collect all the data required for the study which helps to create awareness on cervical cancer about its screening procedures, risk factors, lifestyle modifications and prevention by circulating leaflets, visual presentation, oral and poster presentation to motivate the women for the effective participation in the screening program. We had also collected feedback about the awareness after creating awareness had enlightened the study. 


\section{Study method}

The study was conducted in Guntur. A pilot study was conducted for the readability and understanding of the questionnaire and patient information leaflet. A data collection form was developed in which all the details of the patients are noted. Patients were given adequate knowledge on cervical cancer. Subjects were provided with patient information leaflets on cervical cancer. Patients, as well as illiterates who did not wish to participate in the study, were also be provided with help of patient information leaflets and videos. A self-administered questionnaire was given to the subjects who have given their willingness to participate in the study. A risk assessment questionnaire was distributed to the subjects after assessing the self-administered questionnaire. Risk assessment to the subjects who were married, completed family or patients with a positive family history. Risk assessment was done by using an online risk assessment tool and patients shall be informed as to what level they were at risk. Patients were advised for effective screening procedures. Consent was taken from subjects who underwent screening. Patients who understood that they were at risk were advised for screening which was further conducted by the physician and counseled about their lifestyle modifications. A feedback form was distributed randomly to find out the better outcomes of the study. The difference in the knowledge levels was observed. The data was analyzed using a descriptive analysis, Likert's scale, Chisquare, and P-test [5].

\section{Ethical approval}

Ethical approval was taken with a no.10 from Guntur Medical College.

\section{RESULTS}

Awareness on cervical cancer was created among 1000 people. This study was conducted during the period of $1^{\text {st }}$ January to $30^{\text {th }}$ June i.e. for a period of 6 mo $[6,7,10]$.

Table 1: Age and gender wise distribution

\begin{tabular}{|c|c|c|c|c|}
\hline Age group & Males & Females & Total & Percentage \\
\hline $16-20$ & 113 & 346 & 459 & $45.9 \%$ \\
\hline $20-30$ & 50 & 138 & 188 & $18.8 \%$ \\
\hline $30-40$ & 36 & 70 & 106 & $10.6 \%$ \\
\hline $40-50$ & - & 120 & 120 & $12.0 \%$ \\
\hline $50-60$ & - & 117 & 117 & $11.7 \%$ \\
\hline $60-70$ & - & 10 & 10 & $1 \%$ \\
\hline
\end{tabular}

Table 2: Sociodemographic characteristics of the respondents $(\mathrm{N}=\mathbf{1 0 0 0})$

\begin{tabular}{|c|c|c|c|c|}
\hline \multicolumn{5}{|l|}{ Educational stream } \\
\hline & Males & Females & Total & Percentage (\%) \\
\hline Science & $126(31.11 \%)$ & $279(68.8 \%)$ & 405 & $40.5 \%$ \\
\hline Non-science & $135(22.7 \%)$ & $460(77.3 \%)$ & 595 & $59.5 \%$ \\
\hline \multicolumn{5}{|l|}{ Education level } \\
\hline Intermediate & - & $48(100 \%)$ & 48 & $4.8 \%$ \\
\hline Degree (B. com and B. sc) & $59(60.8 \%)$ & $38(39.2 \%)$ & 97 & $9.7 \%$ \\
\hline Pharmacy & $126(31.11 \%)$ & $279(68.8 \%)$ & 405 & $40.5 \%$ \\
\hline Engineering & - & $227(100 \%)$ & 227 & $22.7 \%$ \\
\hline \multicolumn{5}{|l|}{ Others } \\
\hline Literates & $23(15.4 \%)$ & $30(84.6 \%)$ & 65 & $6.5 \%$ \\
\hline Illiterates & $40(66.6 \%)$ & $118(83.3 \%)$ & 158 & $15.8 \%$ \\
\hline \multicolumn{5}{|l|}{ Marital status } \\
\hline Married & $60(14.6 \%)$ & $350(85.3 \%)$ & 410 & $41 \%$ \\
\hline Unmarried & $130(22.0 \%)$ & $460(77.9 \%)$ & 590 & $59 \%$ \\
\hline
\end{tabular}

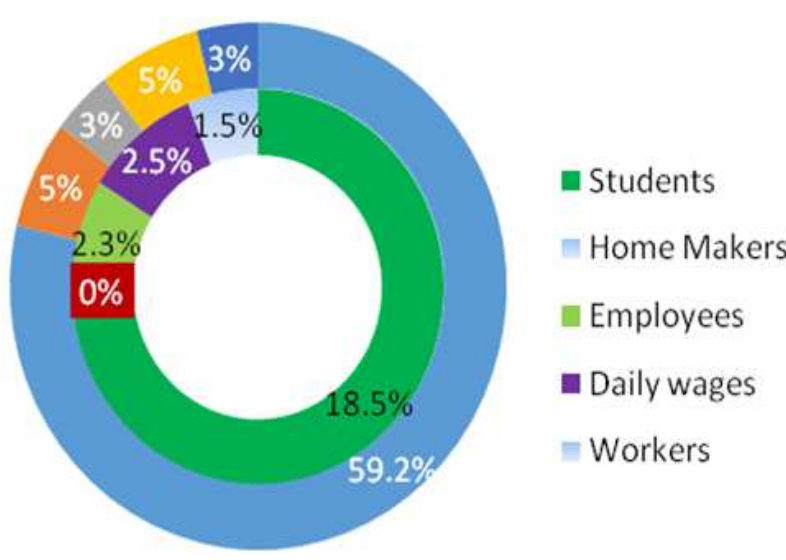

Fig. 1: Among 1000 population, 752 (75.2\%) were females and $248(24.8 \%)$ were males. Out of 752 females, 592 (59.2\%) members were students, 50 (5\%) were homemakers, 30 (3\%) were employees, $50(5 \%)$ were daily wages, $30(3 \%)$ were workers. Out of 248 males, 185 (18.5\%) were students, 23

(2.3\%) were employees, 25 (2.5\%) were daily wages, 15 (1.5\%) were workers. Among all the population majority of the respondents were students
Table 1 Majority of population fall between the age group of $16-20 \mathrm{y}$ i.e. (459) $45.9 \%$ followed by $20-30$ y $188(18.8 \%$ ) and least was found in 30-40 y $106(10.6 \%)$. Among all the age groups of the study, most of the respondents were identified as females.

Table 2: Total numbers of the population included in the study were 1000 members. Out of 1000 members, much of population 595 members $(59.5 \%)$ belong to the non-science background and 405 members $(40.5 \%)$ belong to the science background. Many population 405 members $(40.5 \%)$ belong to the pharmacy profession and $48(4.8 \%)$ members belong to the intermediate. Other than the students, 158 members (15.8\%) are illiterates and 65 (6.5\%) members are literates. Among them, 590 members (59\%) are unmarried and 410 members $(41 \%)$ are married.

Table 3 Total numbers of the population included in the study were 1000 . Out of 1000 members, 405 members (40.5\%) belonging to the science field have said that they heard about cervical cancer and 595 members (59.5\%) answered that they don't know about cervical cancer. Much of the population i.e. 595 members (59.5\%) belongs to the non-science background answered that they don't know about the causative organism whereas, 405 members $(40.5 \%)$ belongs to the science background answered that they know about the causative organism of cervical cancer. Out of 1000, 595 members $(59.5 \%)$ are not aware of the HPV vaccine whereas, 405 members (40.5\%) were aware of HPV vaccine. 
Table 3: Level of awareness

\begin{tabular}{|c|c|c|c|c|c|c|c|c|}
\hline \multirow[t]{2}{*}{ Questionnaire } & \multicolumn{2}{|l|}{ Yes } & \multicolumn{2}{|l|}{ No } & \multicolumn{2}{|l|}{ Total } & \multicolumn{2}{|c|}{ Percentage } \\
\hline & Science & $\begin{array}{l}\text { Non- } \\
\text { science }\end{array}$ & Science & $\begin{array}{l}\text { Non- } \\
\text { science }\end{array}$ & Science & $\begin{array}{l}\text { Non- } \\
\text { science }\end{array}$ & Science & $\begin{array}{l}\text { Non- } \\
\text { science }\end{array}$ \\
\hline Have you heard about cervical cancer? & $150(30.9 \%)$ & $50(8.4 \%)$ & $255(62.9 \%)$ & $545(91.5 \%)$ & 405 & 595 & $40.5 \%$ & $59.5 \%$ \\
\hline $\begin{array}{l}\text { Do you know about the causative } \\
\text { organism for cervical cancer? }\end{array}$ & $\begin{array}{l}60 \\
(14.8 \%)\end{array}$ & $10(1.6 \%)$ & $345(77.5 \%)$ & $585(98.3 \%)$ & 405 & 595 & $40.5 \%$ & $59.5 \%$ \\
\hline $\begin{array}{l}\text { Have you heard about the HPV vaccine } \\
\text { for cervical cancer? }\end{array}$ & $\begin{array}{l}70 \\
(17.2 \%)\end{array}$ & $30(5.0 \%)$ & $335(82.7 \%)$ & $565(94.9 \%)$ & 405 & 595 & $40.5 \%$ & $59.5 \%$ \\
\hline
\end{tabular}

\section{Before creating awareness}

Table 4: Have you heard about cervical cancer

\begin{tabular}{|c|c|c|c|c|c|}
\hline Variables & Yes & No & Total & $\times 2$ Value & P-Value \\
\hline \multicolumn{6}{|l|}{ Age in y } \\
\hline $16-20$ & $109(23.7 \%)$ & $350(16.3 \%)$ & $459(45.9 \%)$ & 70.25 & $<0.0001$ \\
\hline $20-30$ & $88(46.8 \%)$ & $100(53.2 \%)$ & $188(18.8 \%)$ & & \\
\hline $30-40$ & $20(18.0 \%)$ & $86(81.0 \%)$ & $106(10.6 \%)$ & & \\
\hline $40-50$ & $40(33.3 \%)$ & $80(66.6 \%)$ & $120(12.0 \%)$ & & \\
\hline $50-60$ & $10(8.5 \%)$ & $107(91.4 \%)$ & $117(11.7 \%)$ & & \\
\hline $60-70$ & 0 & $10(100 \%)$ & $10(1 \%)$ & & \\
\hline \multicolumn{6}{|l|}{ Educational stream } \\
\hline Science & $150(30.9 \%)$ & $255(62.9 \%)$ & $405(40.5 \%)$ & 105.5 & $<0.0001$ \\
\hline Non-science & $60(10.1 \%)$ & $535(89.9 \%)$ & $595(59.5 \%)$ & & \\
\hline Educational level & $8(16.6 \%)$ & $40(83.3 \%)$ & $48(4.8 \%)$ & & \\
\hline Intermediate & $10(10.3 \%)$ & $87(89.7 \%)$ & $97(9.7 \%)$ & 170.1 & $<0.0001$ \\
\hline Degree (B. com and B. sc) & $200(49.4 \%)$ & $205(50.6 \%)$ & $405(40.5 \%)$ & & \\
\hline Pharmacy & $20(8.8 \%)$ & $207(91.2 \%)$ & $227(22.7 \%)$ & & \\
\hline Engineering & $15(30 \%)$ & $35(70 \%)$ & $50(5 \%)$ & & \\
\hline Housewife's & $33(62.3 \%)$ & $20(37.7 \%)$ & $53(5.3 \%)$ & & \\
\hline Employees & $15(20 \%)$ & $60(80 \%)$ & $75(7.5 \%)$ & & \\
\hline Daily wages & $10(22.2 \%)$ & $35(77.7 \%)$ & $45(4.5 \%)$ & & \\
\hline \multicolumn{6}{|l|}{ Workers } \\
\hline \multicolumn{6}{|l|}{ Marital status } \\
\hline Married & $200(48.8 \%)$ & $210(51.2 \%)$ & $410(41 \%)$ & 30.00 & $<0.0001$ \\
\hline Unmarried & $390(66.1 \%)$ & $200(33.9 \%)$ & $590(59 \%)$ & & \\
\hline \multicolumn{6}{|l|}{ Gender } \\
\hline Males & $80(32.3 \%)$ & $168(67.7 \%)$ & 248 (24.8\%) & 4.165 & 0.0317 \\
\hline Females & $300(39.9 \%)$ & $452(60.1 \%)$ & $752(75.2 \%)$ & & \\
\hline
\end{tabular}

Table 4: Total numbers of people included in the study were 1000. Out of 1000 members, much of population i.e. 459 members $(45.9 \%)$ belongs to the age group of $16-20 \mathrm{y}$ and the least population i.e. 10 members (1\%) belongs to the age group of $60-70 \mathrm{y}$. The $x^{2}$ value is $70.25 \%$ and $\mathrm{P}$ value is $<0.0001$. Regarding the educational stream, many populations i.e. 595(59.5\%) members belong to the non- science background and least number of population i.e. 405 members $(40.5 \%)$ belong to the science background. Much of population 405 members $(40.5 \%)$ belong to the pharmacy background and least number of population 45 members $(4.5 \%)$ were workers. Much of the population 752 members $(75.2 \%)$ are females and 248 members (24.8\%) are males.

Table 5: How many know about the causative organism for cervical cancer

\begin{tabular}{|c|c|c|c|c|c|}
\hline Variables & Yes & No & Total & $x^{2}$ value & p-value \\
\hline \multicolumn{6}{|l|}{ Age in $y$} \\
\hline $16-20$ & $70(15.3 \%)$ & $389(84.7 \%)$ & $459(45.9 \%)$ & \multirow[t]{6}{*}{36.41} & \multirow[t]{6}{*}{$<0.0001$} \\
\hline $20-30$ & $50(26.5 \%)$ & $138(73.4 \%)$ & $188(18.8 \%)$ & & \\
\hline $30-40$ & $20(18.0 \%)$ & $86(81.0 \%)$ & $106(10.6 \%)$ & & \\
\hline $40-50$ & $10(8.3 \%)$ & $110(91.6 \%)$ & $120(12.0 \%)$ & & \\
\hline $50-60$ & $5(4.3 \%)$ & $112(95.7 \%)$ & $117(11.7 \%)$ & & \\
\hline $60-70$ & 0 & $10(100 \%)$ & $10(1 \%)$ & & \\
\hline \multicolumn{6}{|l|}{ Educational stream } \\
\hline Science & $150(30.9 \%)$ & $255(62.9 \%)$ & $405(40.5 \%)$ & \multirow[t]{2}{*}{105.5} & \multirow[t]{2}{*}{$<0.0001$} \\
\hline Non-science & $60(10.1 \%)$ & $535(89.9 \%)$ & $595(59.5 \%)$ & & \\
\hline \multicolumn{6}{|l|}{ Educational level } \\
\hline Intermediate & 0 & $48(100 \%)$ & $48(4.8 \%)$ & \multirow[t]{8}{*}{203.0} & \multirow[t]{8}{*}{$<0.0001$} \\
\hline Degree (B. com and B. sc) & 0 & $97(100 \%)$ & $97(9.7 \%)$ & & \\
\hline Pharmacy & $150(37.3 \%)$ & $255(63 \%)$ & $405(40.5 \%)$ & & \\
\hline Engineering & 0 & $227(100 \%)$ & $227(22.7 \%)$ & & \\
\hline Homemakers & $10(20 \%)$ & $40(80 \%)$ & $50(5 \%)$ & & \\
\hline Employees & $15(28.3 \%)$ & $38(71.7 \%)$ & $53(5.3 \%)$ & & \\
\hline Daily wages & 0 & $75(100 \%)$ & $75(7.5 \%)$ & & \\
\hline Workers & $5(11.1 \%)$ & $40(88.8 \%)$ & $45(4.5 \%)$ & & \\
\hline \multicolumn{6}{|l|}{ Marital status } \\
\hline Married & $100(24.4 \%)$ & $310(75.6 \%)$ & $410(41 \%)$ & \multirow[t]{3}{*}{10.41} & \multirow[t]{2}{*}{$<0.0001$} \\
\hline Unmarried & $200(33.9 \%)$ & $390(66.1 \%)$ & $590(59 \%)$ & & \\
\hline \multicolumn{5}{|l|}{ Gender } & \\
\hline Males & $50(20 \%)$ & $198(79.8 \%)$ & $248(24.8 \%)$ & \multirow[t]{2}{*}{29.32} & \multirow[t]{2}{*}{$<0.0001$} \\
\hline Females & $200(25 \%)$ & $300(37.5 \%)$ & $752(75.2 \%)$ & & \\
\hline
\end{tabular}


Table 5: Total numbers of people included in the study were 1000 members. Out of 1000 members, the highest number of population i.e. 459 members ( $45.9 \%$ ) belong to the age group of $16-20 y$. The $x^{2}$ value is 36.41 and $p$-value is $<0.0001$. Regarding the educational stream, many populations i.e. 595(59.5\%) members belongs to the nonscience background and least number of population i.e. 405 members $(40.5 \%)$ belong to the science background. Much of population 405 members $(40.5 \%)$ belong to the pharmacy profession and least number i.e. 45 members are the workers. Most the population, 590 members (59\%) were unmarried and 410 members (41\%) were married. Much of the population were females.
Table 6: Total number of people included in the study was 1000 members. Out of 1000 members, 459 members (45.9\%) belong to the age group of $16-20 \mathrm{y}$ and least number of population 10 members (1\%) belongs to the age group of $60-70$. The $x^{2}$ value is 70.17 and p-value is 0.0001 . Regarding the educational stream, most population i.e. 595(59.5\%) members belongs to the non-science background and least number of population i.e. 405 members (40.5\%) belong to the science background. Much of population 405 members (40.5\%) belong to the pharmacy profession and least number i.e. 45 members are the workers. Many the populations, 590 members (59\%) were unmarried and 410 members (41\%) were married. Much of the population was females.

Table 6: Have you heard about the HPV vaccine for cervical cancer

\begin{tabular}{|c|c|c|c|c|c|}
\hline Variables & Yes & No & Total & $\times 2$ value & p-value \\
\hline \multicolumn{6}{|l|}{ Age } \\
\hline $16-20$ & $30(6.53 \%)$ & $429(93.5 \%)$ & $459(45.9 \%)$ & 70.17 & $<0.0001$ \\
\hline $20-30$ & $60(16.0 \%)$ & $158(84 \%)$ & $188(18.8 \%)$ & & \\
\hline $30-40$ & $20(18.9 \%)$ & $86(81.1 \%)$ & $106(35.3 \%)$ & & \\
\hline $40-50$ & $20(16.6 \%)$ & $100(83.3 \%)$ & $120(12.0 \%)$ & & \\
\hline $50-60$ & $5(4.2 \%)$ & $107(91.4 \%)$ & $117(11.7 \%)$ & & \\
\hline $60-70$ & 0 & $10(100 \%)$ & $10(1 \%)$ & & \\
\hline \multicolumn{6}{|l|}{ Educational stream } \\
\hline Science & $100(24.7 \%)$ & $305(75.3 \%)$ & $405(40.5 \%)$ & 64.62 & $<0.0001$ \\
\hline Non-science & $40(6.7 \%)$ & $555(93.3 \%)$ & $595(59.5 \%)$ & & \\
\hline \multicolumn{6}{|l|}{ Educational level } \\
\hline Intermediate & 0 & $48(100 \%)$ & $48(4.8 \%)$ & 121.8 & $<0.0001$ \\
\hline Degree (B. com and B. sc) & 0 & $97(100 \%)$ & $97(9.7 \%)$ & & \\
\hline Pharmacy & $84(20.7 \%)$ & $321(79.3 \%)$ & $405(40.5 \%)$ & & \\
\hline Engineering & 0 & $227(100 \%)$ & $227(22.7 \%)$ & & \\
\hline Housewife's & $5(10 \%)$ & $45(90 \%)$ & $50(5 \%)$ & & \\
\hline Employees & $15(28.3 \%)$ & $38(71.7 \%)$ & $53(5.3 \%)$ & & \\
\hline Daily wages & 0 & $75(100 \%)$ & $75(7.5 \%)$ & & \\
\hline Workers & 0 & $45(100 \%)$ & $45(4.5 \%)$ & & \\
\hline \multicolumn{6}{|l|}{ Marital status } \\
\hline Married & $20(4.9 \%)$ & $390(95.1 \%)$ & $410(41 \%)$ & 22.74 & $<0.0001$ \\
\hline Unmarried & $84(14.2 \%)$ & $506(85.8 \%)$ & $590(59 \%)$ & & \\
\hline \multicolumn{6}{|l|}{ Gender } \\
\hline Males & $40(20 \%)$ & 208 (20.8\%) & 248 (24.8\%) & 11.62 & $<0.0001$ \\
\hline Females & $64(8 \%)$ & $688(68.8 \%)$ & $752(75.2 \%)$ & & \\
\hline
\end{tabular}

After creating awareness

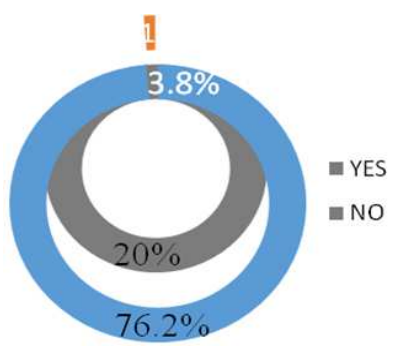

Fig. 2: After providing knowledge by pictures and presentation, the respondents $762(76.2 \%)$ females and $200(20 \%)$ males are aware of cervical cancer. In females, $10(1 \%)$ and males $(3.8 \%)$ were partially aware of cervical cancer

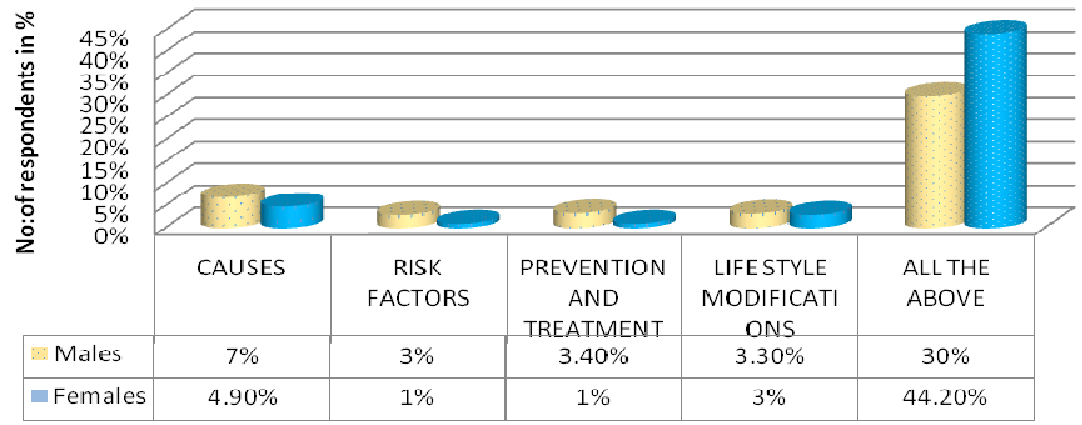

Fig. 3: Among all the respondents 70 (7\%) males, 49 (4.9\%) females were aware of causes, 30 (3\%) males and 10 (1\%) females were aware of risk factors, $34(3.4 \%)$ males and 10 (1\%) females were aware of prevention and treatment, $33(3.3 \%)$ males and 30 (3\%) females were aware of lifestyle modifications, $442(44.2 \%)$ females and $300(30 \%)$ males were highly aware of all the factors such as causes, risk factors, prevention and treatment, lifestyle modifications 
Females: $10(1 \%)$ were least aware of risk factors, prevention, and treatment

Males: 30 (3\%) were least aware of risk factors

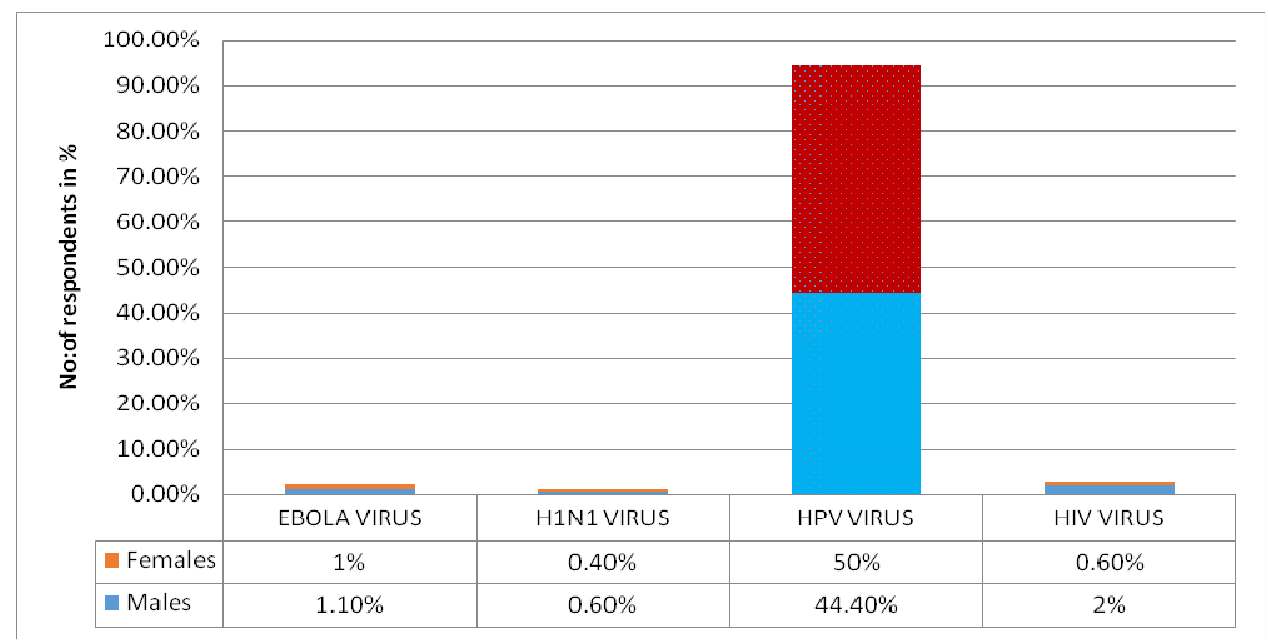

Fig. 4: Among all the respondents 500 (50\%) females and 444 (44.4\%) males answered correctly to HPV virus

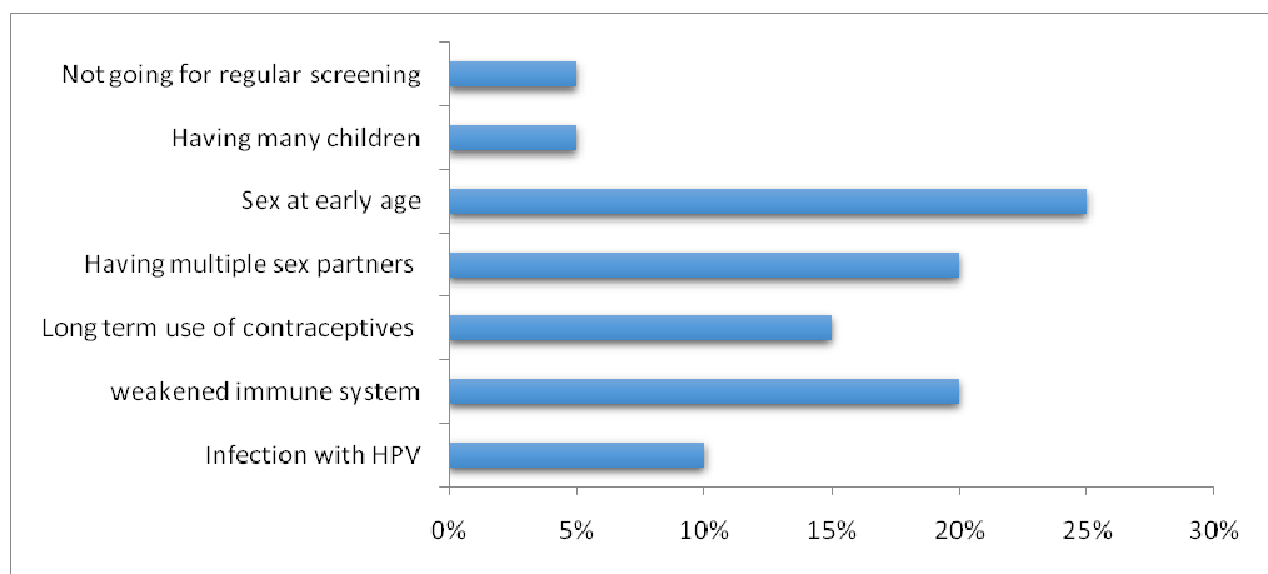

Fig. 5: Total number of people included in the study were 1000, among 1000 members, the highest number of people (25\%) had chosen that sex at an early age is the major risk factor for cervical cancer. Least number of people (5\%) had chosen that having many children and not going for regular screening are the risk factors

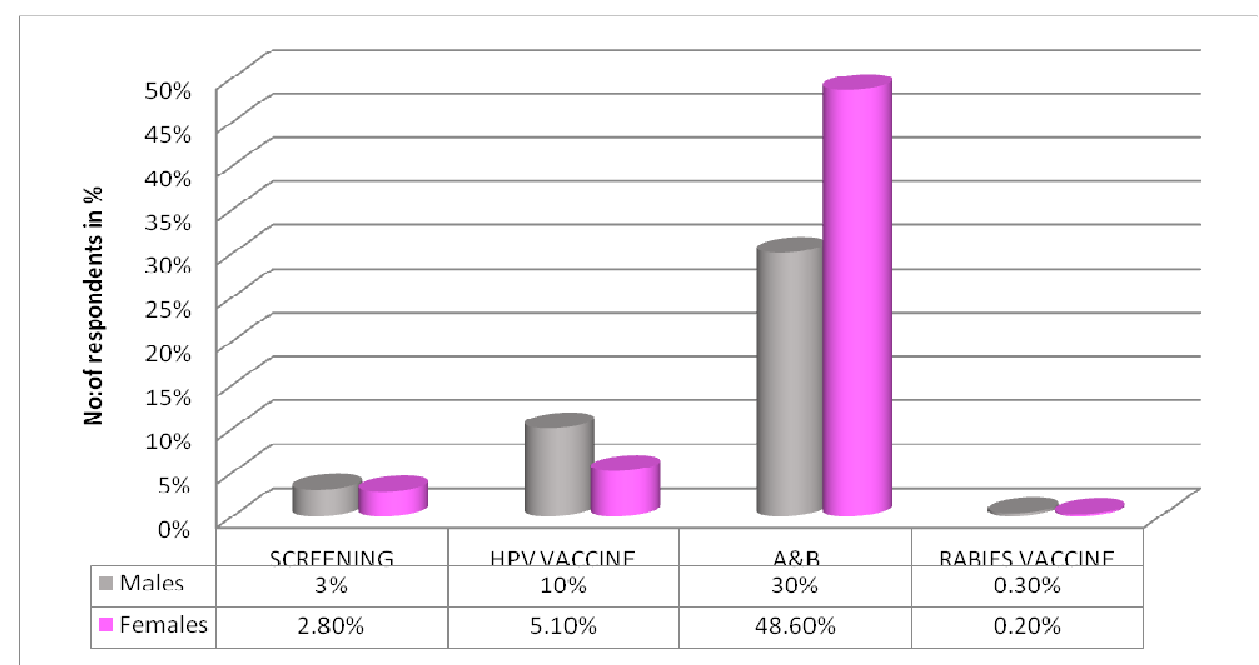

Fig. 6: Among all the respondents 486 (48.6\%) females and 300 (30\%) males had chosen the correct answer that screening and HPV vaccine were the preventive steps to be taken 


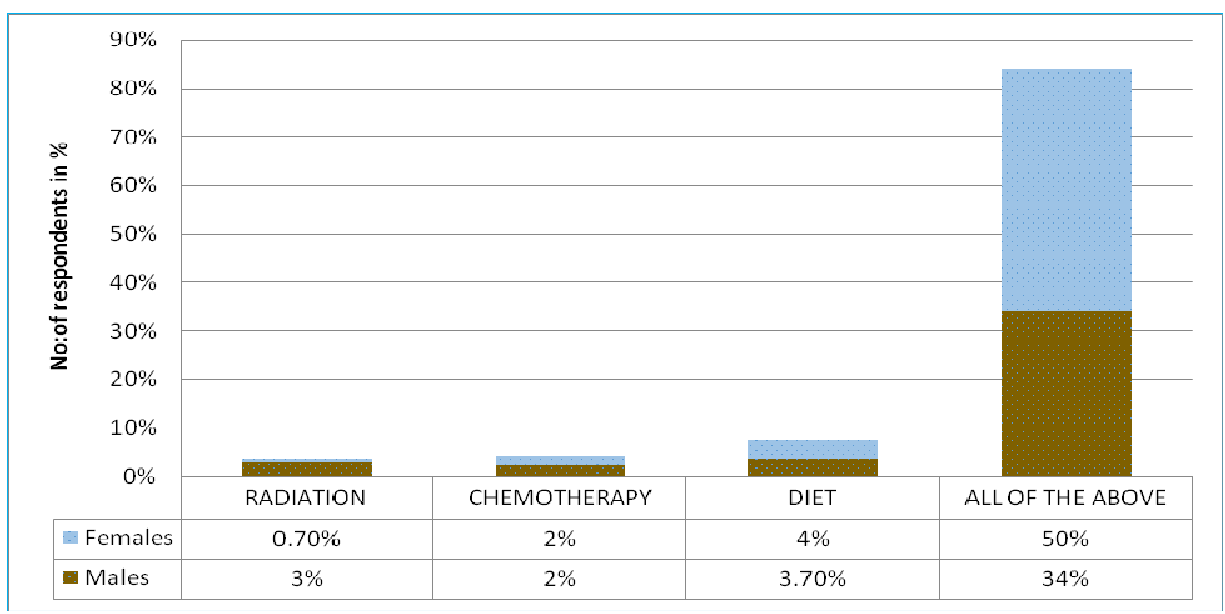

Fig. 7: Among all the respondents 500 (50\%) females and 340 (34\%) males chosen radiation, chemotherapy, and dietary changes were the treatment options for cervical cancer

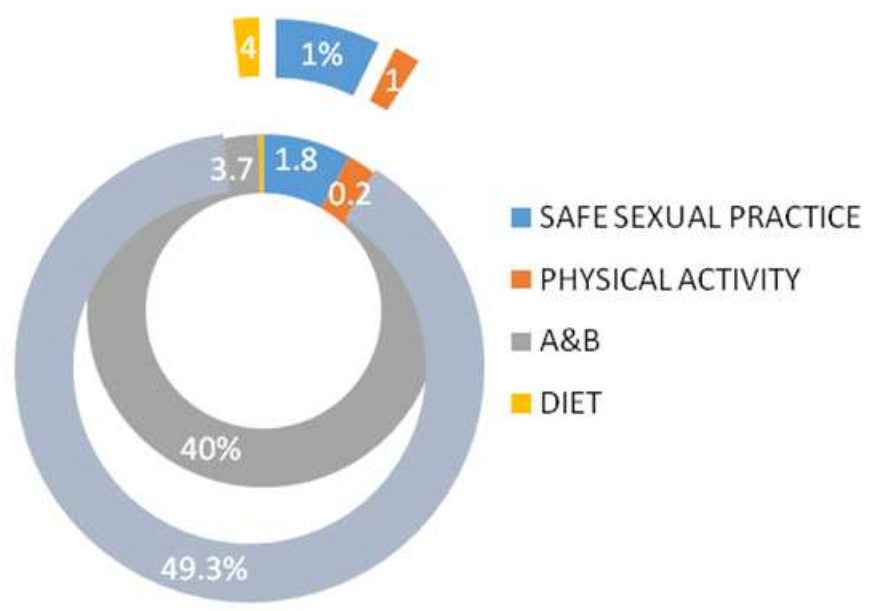

Fig. 8: Among all the respondents 493 (49.3\%) females and 400 (40\%) males, $1 \%$ had agreed that safe sexual practice, $1 \%$ had agreed that physical activity and $4 \%$ had agreed that diet were the lifestyle modifications to be followed

Table 7: Level of satisfaction

\begin{tabular}{llllll}
\hline Questionnaire & $\begin{array}{l}\text { Not all } \\
\text { satisfied }\end{array}$ & $\begin{array}{l}\text { Slightly } \\
\text { satisfied }\end{array}$ & $\begin{array}{l}\text { Moderately } \\
\text { satisfied }\end{array}$ & $\begin{array}{l}\text { Very } \\
\text { satisfied }\end{array}$ & $\begin{array}{l}\text { Extremely } \\
\text { satisfied }\end{array}$ \\
\hline Have you understood the matter explained? & NILL & NILL & 310 & 372 & 318 \\
& & & $31 \%$ & $37.2 \%$ & $31.8 \%$ \\
& NILL & 50 & 202 & 534 & 214 \\
Are you satisfied with the information provided? & & $5 \%$ & $20.2 \%$ & $53.4 \%$ & $21.4 \%$ \\
Do you want any other information about cervical cancer? & NILL & NILL & 169 & 283 & 548 \\
& & & $16.9 \%$ & $28.3 \%$ & $54.8 \%$ \\
\hline
\end{tabular}

Table 7: Out of 1000 members, most the population i.e. 372 members $(37.2 \%)$ are very satisfied, 318 members $(31.8 \%)$ were extremely satisfied and 310 members (31\%) were moderately satisfied with the matter explained. Much of population i.e. 534 members (53.4\%) are very satisfied, 214 members (21.4\%) were extremely satisfied, 202 members
(20.2\%) were moderately satisfied, and 50 members (5\%) were slightly satisfied with the information provided. The majority of population i.e. 548 members $(54.8 \%)$ were extremely satisfied, 283 members $(28.3 \%)$ were very satisfied and 169 members (16.9\%) were moderately satisfied with the information provided on cervical cancer.

Table 8: Distribution of respondents about screening

\begin{tabular}{lll}
\hline Questions on screening & Yes & No \\
\hline Have you heard of cervical cancer screening tests & $4(8.3 \%)$ & $44(91.6 \%)$ \\
Have you heard of centers that do cervical screening tests & 00 & $48(100 \%)$ \\
Have you done cervical screening tests in the past & $04(8.3 \%)$ & $44(91.6 \%)$ \\
Will you like to do cervical cancer screening tests if the services are available locally & $26(54.0 \%)$ & $22(45.0 \%)$ \\
Have you ever had a hysterectomy & $29(60.2 \%)$ & $19(39.0 \%)$ \\
Have you ever had a sexually transmitted disease (STD's) & $48(100 \%)$ & 00 \\
\hline
\end{tabular}


Table 8: To find out the opinion and awareness about screening this questionnaire were distributed among the respondents $(n=48)$. For the question "if they have ever heard about cervical cancer screening tests" only 4(8.3\%) answered positively and remaining 44(91.6\%) have answered that they did not know. Another question "if they knew about the centers for cervical screening" none of them answered positively. $4(8.3 \%)$ answered positively and remaining $44(91.6 \%)$ have answered that they have not undergone cervical cancer screening in the past. Out of 48 members, 29(60.2\%) had a history of partial hysterectomy and $19(39.0 \%)$ have not undergone a hysterectomy. All of them were aware of sexually transmitted diseases (STD's).

\section{Risk assessment}

Table 9: Frequency distribution of symptoms and screening procedures among women

\begin{tabular}{|c|c|c|c|c|c|c|}
\hline \multirow[t]{2}{*}{ Age } & \multicolumn{3}{|l|}{ Symptoms } & \multicolumn{2}{|c|}{ Pap smear underwent } & \multirow[t]{2}{*}{ Percentage \% } \\
\hline & Yes & No & Total & Yes & No & \\
\hline $20-30$ & $12(25 \%)$ & 66 & 78 & 12 & 66 & 22.0 \\
\hline $30-40$ & $8(16.6 \%)$ & 87 & 95 & 8 & 87 & 26.91 \\
\hline $40-50$ & $9(18.7 \%)$ & 51 & 60 & 9 & 51 & 16.9 \\
\hline $50-60$ & $6(12.5 \%)$ & 59 & 65 & 6 & 59 & 18.41 \\
\hline $60-70$ & $13(27 \%)$ & 42 & 55 & 13 & 42 & 15.51 \\
\hline Total & $48(100)$ & 305 & 353 & 48 & 305 & 100 \\
\hline
\end{tabular}

Table 9: Out of 353 members, who are included in screening 305 members do not have any symptoms pertaining to the suspecting disease. Out of 353 members, 78 members (22\%) belongs to the age group of 20-30, 95 members (26.9\%) belongs to the age group of $30-40,60(16.9 \%)$ members belong to $40-50 \mathrm{y}, 65(18.41 \%)$ belongs to the age group of 50-60 y and 55(15.51\%) members belong to the age group of 60-70 y. The risk assessment was done for 48 patients were positive with the symptoms. Out of these 48 patients, $12(25 \%)$ members of the age group of 20-30years have undergone pap-smear and 66 members have not undergone pap- smear. Among $8(16.6 \%)$ members of the age group of 30-40 have undergone pap-smear and 87(26.91\%) members have not undergone pap-smear. Among $9(18.7 \%)$ members who have undergone pap-smear belong to the age group of 40-50years, and 51(16.9\%) members have not undergone the pap-smear test. Among 6(12.5\%) members who undergone the pap-smear belong to the age group of 50-60 y, and 59 members have not undergone pap-smear. 13(27\%) members have undergone for pap-smear test belongs to the age group of $60-70 \mathrm{y}$ and $42(15.51 \%)$ members have not undergone pap-smear [8].

Table 10: Frequency distribution of symptoms among women

\begin{tabular}{lll}
\hline Symptoms & Number & Percentage \% \\
\hline Vaginal discharge & 3 & 6.2 \\
Post coital bleeding & 2 & 4.1 \\
Menstrual irregularities & 9 & 18.7 \\
Post-menopausal bleeding & 6 & 12.6 \\
Hormonal imbalances & 11 & 22.9 \\
Other complaints & 17 & 35.4 \\
Total & 48 & 100 \\
\hline
\end{tabular}

Table 10: Among the females 353, 48(13.5\%) have attended to the screening. Certain symptoms such as vaginal discharge $3(6.2 \%)$, post coital bleeding 2 (4.1\%), menstrual irregularities $9(18.7 \%)$, post-menopausal bleeding $6(12.6 \%)$, hormonal imbalances 11(22.9), other complaints such as PCOS, infertility, back pain, lower abdominal pain 17 have been observed [9].

Table 11: Findings of pap smear among different age groups in women

\begin{tabular}{|c|c|c|c|c|c|c|}
\hline Cytological diagnosis on pap smear & $20-30$ & $30-40$ & 40-50 & $50-60$ & $60-70$ & Percentage \% \\
\hline Papillary endo-cervicitis & $2(4.1 \%)$ & - & $1(2.0 \%)$ & - & - & 6.25 \\
\hline Bacterial vaginosis & - & $1(2.0 \%)$ & - & $3(6.2 \%)$ & $1(2.0 \%)$ & 10.41 \\
\hline Atrophic smear inflammatory changes & $2(4.1 \%)$ & - & $1(2.0 \%)$ & - & $1(2.0 \%)$ & 8.33 \\
\hline Inflammatory smear & - & $3(6.2 \%)$ & $1(2.0 \%)$ & $2(4.1 \%)$ & - & 12.5 \\
\hline Epithelial abnormalities & - & - & - & - & - & 00 \\
\hline Candidial cervicitis & - & - & $2(4.1 \%)$ & - & - & 4.16 \\
\hline Dysplastic squamous epithelial cells & - & - & - & $1(2.0 \%)$ & - & 2.08 \\
\hline Squamous cell carcinoma differentiated & - & - & - & $1(2.0 \%)$ & - & 2.08 \\
\hline Squamous cell carcinoma undifferentiated & - & - & - & - & $1(2.0 \%)$ & 2.08 \\
\hline
\end{tabular}

Table 11: Among the 48 women who attended the screening, 23(47.9\%) were identified with various symptoms. They have been categorized based on the age groups. It was found that between the age group of $20-30 \mathrm{y}, 2(4.1 \%)$ and $1(2.0 \%)$ in the age group of $40-50 \mathrm{y}$. A total of $3(6.25 \%)$ were identified with papillary endo-cervicitis. Among $30-40 \mathrm{y}, 1(2.0 \%), 3(6.2 \%)$ in the age group of $50-60 \mathrm{y}$ and $1(2.0 \%)$ in the age group of $60-70 \mathrm{y}$. A total of $5(10.4 \%)$ were known to be bacterial vaginosis. A total of $4(8.25 \%)$ were identified with atrophic inflammatory changes. Between the age group of 20-30 y
$2(4.1 \%)$, and $1(2 \%)$ each was identified among the 40-50 and 60-70 y. Among 30-40 y' age group 3(6.2\%), $1(2.0 \%)$ in the age group of $40-50$, $2(4.1 \%)$, in the age group of $50-60$ a total of $6(12.5 \%)$ were identified. No epithelial abnormalities were observed candidial cervicitis. Between the ages group of 40-50 a total of 2(4.1\%). Among 50-60 y of age group, $1(4.1 \%)$ were observed with both dysplastic squamous epithelial cells and squamous cell carcinoma differentiated, while in 60-70 age group also identified with the same number i.e., $1(4.1 \%)$ was known to be squamous cell carcinoma undifferentiated $[11,12]$. 


\section{DISCUSSION}

Out of 1000 population, the respondent's 762 (76.2\%) females and $200(20 \%)$ males are aware of cervical cancer (fig. 1, 2). Among males, 60 were married and 120 were unmarried. Among all these, 459 members belong to the age group of $16-20 \mathrm{y}$. The highest population belongs to the age group of $16-20 \mathrm{y}$ as the maximum population included in the study was students. The age group of 20 $30 \mathrm{y}$ consists of 188 members, 106 members belong to the class of $30-40 \mathrm{y}, 120$ members belong to the age group of 40-50, 117 members belong to the age group of 50-60 and 10 members belong to the age group of 60-70 (table 1). Among 762 females, 38 females are pursuing B. Com and B. Sc., 48 females are pursuing intermediate, 279 members belong to the field of pharmacy and 227 members belong to the engineering background. Out of 200 males, 59 males belong to the field of B. com and B. Sc. whereas, 126 members belong to the pharmacy. Among all the people involved in the study, $84.4 \%$ of the females were literates and $118 \%$ are illiterates, whereas $15.4 \%$ of the males were literates and $66.6 \%$ were illiterates. Among the whole population, 350 females were married and 460 were unmarried (table 2). The highest illiteracy rate is seen in married women [13].

Regarding the level of awareness, out of 1000 members, 405 members $(40.5 \%)$ belonging to the science field have said that they heard about cervical cancer and 595 members (59.5\%) answered that they don't know about cervical cancer. Most the population i.e. 595 members $(59.5 \%)$ belongs to the non-science background answered that they don't know about the causative organism whereas, 405 members (40.5\%) belongs to the science background answered that they know about the causative organism of cervical cancer. Out of 1000, 595 members (59.5\%) are not aware of the HPV vaccine whereas, 405 members $(40.5 \%)$ were aware of $\mathrm{HPV}$ vaccine (table 3 and 5) [14].

Regarding the level of satisfaction, 372 members (37.2\%) are very satisfied, 318 members (31.8\%) were extremely satisfied and 310 members (31\%) were moderately satisfied with the matter explained. Much of population i.e. 534 members (53.4\%) are very satisfied, 214 members (21.4\%) were extremely satisfied, 202 members $(20.2 \%)$ were moderately satisfied, and 50 members $(5 \%)$ were slightly satisfied with the information provided. Most population i.e. 548 members (54.8\%) were extremely satisfied, 283 members $(28.3 \%)$ were very satisfied and 169 members (16.9\%) were moderately satisfied with the information provided on cervical cancer (table 7) [15].

Among all the respondents 500 (50\%) females and 444 (44.4\%) males answered correctly to the question if they (respondents) knew that causative organism is HPV virus after providing the awareness. Out of 1000 respondents, 459 members belong to the age group of 16-20,188 members belong to the age group of 20-30, 106 members belong to the age group of $30-40,120$ members belong to the age group of $40-50,117$ members to the age group of 50-60 and 10 members belong to the age group of 60-70. Among all these respondents, 405 members to the science background, 595 members to the non-science background. Much the population is seen in non-science background as there is maximum strength in engineering colleges and the degree college. The population of nonscience background involves 50 members as homemakers, 53 members as employees, 75 members as daily wages, and 40 members as workers. Employees also include the teaching staff in the educational Institutions where awareness was conducted. The awareness was highly created among the educational institutions and the medical camps and home medication reviews are conducted. Hence homemakers, daily wagers, and some of the workers are involved [16].

Regarding the risk factors all the respondents 70 (7\%) males, 49 $(4.9 \%)$ females were aware of causes, $30(3 \%)$ males and $10(1 \%)$ females were aware of risk factors, $34(3.4 \%)$ males and $10(1 \%)$ females were aware of prevention and treatment, 33 (3.3\%) males and $30(3 \%)$ females were aware of lifestyle modifications, 442 $(44.2 \%)$ females and $300(30 \%)$ males were highly aware of all the factors such as causes, risk factors, prevention and treatment, lifestyle modifications. Among these 1000 members, 405 belong to the science background and 595 members belong to the non-science background (fig. 5).

Among all the respondents $486(48.6 \%)$ females and $300(30 \%)$ males had chosen correct answer that screening and HPV vaccine was the preventive steps to be taken. Among these people 459 belongs to the age group of 16-20 y, 188 members belong to 20-30y, 106 belong to the age group of 30-40 y, 120 members of 40-50 y, 117 members belong to the age group of $50-60 \mathrm{y}$, and 10 members belong to the age group of 60-70 y. The highest number of the population belongs to the age group of $16-20 \mathrm{y}$ as the awareness was conducted the mostly among the educational institutions. Out of these, 48 members are pursuing intermediate, 97 members are pursuing B. com and B. Sc., 405 members belong to the pharmacy stream, 227 members were engineering students and faculty, 50 members are housewives and 53 members are employees. 75 members are daily wages and 45 members are workers. (table 6) Out of these members, 410 members were married and 595 members were unmarried [17].

Regarding the knowledge of risk factors for cervical cancer, the maximum number of population (30\%) has answered that sex at an early age is the major risk factor for cervical cancer. $20 \%$ of the population had answered that weakened immune system is the risk factor. The population of $20 \%$ had answered that it is due to multiple sexual partners. The $15 \%$ of population believed that long-term use of oral contraceptives is the major risk factor whereas, $10 \%$ had answered that it is due to infection with HPV and remaining $5 \%$ of the population had answered that the major risk factor is having many children and not going for regular screening (fig. 5).

It was also observed that most of the population have understood about the risk factors and symptoms associated with cervical cancer. Out of 1000,595 members are not aware of the HPV vaccine whereas, 405 members were aware of HPV vaccine (fig. 6).

Among all the respondents 500 (50\%) females and 340 (34\%) males had chosen radiation, chemotherapy, and dietary changes were the treatment options for cervical cancer.

Among all the respondents 493 (49.3\%) females and 400 (40\%) males, $1 \%$ had agreed that safe sexual practice, $1 \%$ had agreed that physical activity and 40 members $(4 \%)$ had agreed that diet was the lifestyle modifications to be followed.

There are several barriers to the uptake of screening which includes lack of information on cervical cancer, cancer screening is painful, fear of vaginal examination, not allowed by culture religion, lack of female screeners at the facility, and screening is expensive, long distance to the hospital.

Out of 353 members, who are included in screening, 305 members do not have any symptoms pertaining to the suspecting disease. Out of 353 members, 78 members (22\%) belongs to the age group of 20 30,95 members $(26.9 \%)$ belongs to the age group of $30-40$, $60(16.9 \%)$ members belong to $40-50 \mathrm{y}, 65(18.41 \%)$ belongs to the age group of 50-60 y and 55(15.51\%) members belong to the age group of $60-70 \mathrm{y}$. The risk assessment was done for 48 patients were positive with the symptoms. Out of these 48 patients, $12(25 \%)$ members of the age group of 20-30 y have undergone pap-smear and 66 members have not undergone pap-smear. Among $8(16.6 \%)$ members of the age group of 30-40 have undergone pap-smear and $87(26.91 \%)$ members have not undergone pap-smear. Among $9(18.7 \%)$ members who have undergone pap-smear belongs to the age group of $40-50 \mathrm{y}$, and $51(16.9 \%)$ members have not undergone a pap-smear test. Among 6(12.5\%) members who undergone the pap-smear belong to the age group of 50-60 y, and 59 members have not undergone pap-smear. $13(27 \%)$ members have undergone for pap-smear test belongs to the age group of $60-70 \mathrm{y}$ and $42(15.51 \%)$ members have not undergone pap-smear (table 8) [18].

Among the females 353, 48 (13.5\%) have attended to the screening. certain symptoms such as vaginal discharge $3(6.2 \%)$, post-coital bleeding 2 (4.1\%), menstrual irregularities 9(18.7\%), postmenopausal bleeding 6(12.6\%), hormonal imbalances 11(22.9), other complaints such as PCOS, Infertility, back pain, lower abdominal pain 17 has been observed (table 9) [19]. 
Among the 48 women who attended the screening, 23(47.9\%) were identified with various symptoms. They have been categorized based on the age groups. It was found that between the age group of 20-30 y, $2(4.1 \%)$ and $1(2.0 \%)$ in the age group of $40-50 \mathrm{y}$. A total of $3(6.25 \%)$ were identified with papillary endo-cervicitis. Among 30-40 y, $1(2.0 \%), 3(6.2 \%)$ in the age group of $50-60 \mathrm{y}$ and $1(2.0 \%)$ in the age group of $60-70 \mathrm{y}$. A total of $5(10.4 \%)$ were known to be bacterial vaginosis. A total of $4(8.25 \%)$ were identified with atrophic inflammatory changes. Between the age group of $20-30$ y $2(4.1 \%)$, and $1(2 \%)$ each were identified among the 40-50 and 60-70 y. Among 30$40 y^{\prime}$ age group $3(6.2 \%), 1(2.0 \%)$ in the age group of $40-50,2(4.1 \%)$ in the age group of $50-60$. A total of $6(12.5 \%)$. No epithelial abnormalities were observed. candidal cervicitis. Between the ages of $40-50 \mathrm{y}$ were a total of $2(4.1 \%)$. Among $50-60 \mathrm{y}$ of age group, $1(4.1 \%)$ were observed with dysplastic squamous epithelial cells. Squamous cell carcinoma differentiated. Between age group of 50-60 were identified with 1(4.1\%). Among age group of $60-70 \mathrm{y}, 1(4.1 \%)$ were known to be squamous cell carcinoma undifferentiated (table 10,11).

\section{CONCLUSION}

There are significant differences between the knowledge levels before and after creating awareness among the study population. It was also observed that most of the population have understood about the risk factors and symptoms associated with cervical cancer. Regarding the level of awareness, out of 1000 members, 405 members (40.5\%) belonging to the science field have said that they heard about cervical cancer and 595 members (59.5\%) answered that they don't know about cervical cancer. Many the population i.e. 595 members (59.5\%) belongs to the non-science background answered that they don't know about the causative organism whereas, 405 members (40.5\%) belongs to the science background answered that they know about the causative organism of cervical cancer. Out of 1000, 595 members (59.5\%) are not aware of the HPV vaccine whereas, 405 members (40.5\%) were aware of HPV vaccine.

\section{LIST OF ACRONYMS}

DNA-Deoxy-Ribose Nucleic Acid, CIN-Cervical Squamous Intraepithelial Neoplasia, HIV-Human Immunodeficiency Virus, HR-HPVHigh-Risk Oncogenic Human Papillomavirus, HPV-Human Papilloma Virus, VIA-Visual Inspection with Acetic Acid, PAP-Papanicolaou Smear Test, SIL-Squamous Intraepithelial Lesions, PCOS-Poly Cyst Ovarian Syndrome, STDs-Sexually Transmitted Diseases.

\section{LIMITATIONS}

1. Many the population could have been provided awareness.

2. Due to the presence of various barriers, many of the women who might be at risk did not attend for screening.

3. Subjects below $14 \mathrm{y}$ with a positive family history were not assessed for risk [15].

\section{FUTURE DIRECTIONS}

1. Epidemiological studies can be carried out.

2. More studies can be conducted on preventive measures.

3. Any age group more than four years' sexual practice are advised for effective screening procedures [20].

\section{AUTHORS CONTRIBUTIONS}

All the author have contributed equally

\section{CONFLICT OF INTERESTS}

\section{Declared none}

\section{REFERENCES}

1. A Saha, AN Chaudhury, PB howmik, R Chatterjee. Awareness of cervical cancer among female students of premier colleges in Kolkata, India: Asian Pac J Cancer Prev 2010;11:1085-90.

2. Amosu AM, Degun AM, Babalola AO, Thomas MA. Level of specific knowledge, awareness, perception, and screening behaviour regarding carcinoma of the cervix among rural women in Iwo local Government Area, Osun State, Nigeria. Ann Biol Res 2011;2:206-21.

3. CH Rama, LL Villa, S Pagliusi, MA Andreoli, MC Costa, AL Aoki, AL Filho, JEluf-Neto. Awareness and knowledge of HPV, cervical cancer, and vaccines in young women after first delivery in São Paulo, Brazil-a cross-sectional study. BMC Women's Health 2010;10:35:1472-4

4. DC Johnson, MP Bhatta, S Gurung, SAP Lhaki, S Shrestha. Knowledge and awareness of human papillomavirus (HPV), cervical cancer and HPV vaccine among women in two distinct Nepali communities. Asian Pac J Cancer Prev 2014;15:8287-93.

5. EC Interis, Chidinma P Anakwenze, M Aung, PE Jolly. Increasing cervical cancer awareness and screening in Jamaica: effectiveness of a theory-based educational intervention: a cross-sectional study. Int J Environ Res Public Health 2016;13:3390.

6. FS Hodge, HA Stubbs, V Gurgin, L Fredericks. Cervical cancer screening knowledge, attitudes, and behaviour of American Indian women. Am Cancer Soc 1998;83:1799-804.

7. G Ertem. Awareness of cervical cancer risk factors and screening behaviour among nurses in a rural region of turkey: a cross-sectional study. Asian Pac J Cancer Prev 2009;10:735-8.

8. G Guvenc, A Akyuz, CH Acikel. Health belief model scale for cervical cancer and pap smear test: psychometric testing. J Adv Nurs 2011;2:428-37.

9. K Jaglarz, KA Tomaszewski, W Kamzol, M Puskulluoglu, K Krzemieniecki. Creating and field-testing the questionnaire for the assessment of knowledge about cervical cancer and its prevention among schoolgirls and female students. Gynecol Oncol 2013;25:81-9.

10. LW Smith, F Khurshed, DJV Niekerk, M Krajden, SB Greene, S Hobbs, et al. Women's intentions to self-collect samples for human papillomavirus testing in an organized cervical cancer screening program. BMC Public Health 2014;14:1471-2458.

11. N Sogukpınar, BK Saydam, H Ozturk Can, A Hadıml, OD Bozkurt, U Yücel, et al. Assessment of cervical cancer risk in women between 15 and 49 Y of age. Asian Pac J Cancer Prev 2013;14:2119-25.

12. Owoeye IOG, Ibrahim IA. Knowledge and attitude towards cervical cancer screening among female students and staff in a tertiary institution in the Niger Delta. Int J Management Business Res 2013:2:48-56.

13. Elizabeth AM, Anne WT, W Peter. Awareness of cervical cancer risk factors and practice of Pap smear testing among female primary school teachers in Kasarani division, Nairobi Kenya. Afr J Health Sci 2012;21:121-32.

14. PE Castle, M Sideri, J Jeronimo, D Solomon, M Schiffman. Risk assessment to guide the prevention of cervical cancer. Am J Obstet Gynecol 2007;197:356, e1-e6.

15. RM Austin, A Onisko, MJ Druzdzel. The pittsburgh cervical cancer screening model-a risk assessment tool. Arch Pathol Lab Med 2010;134:744-50.

16. SZ Assoumou, BM Mabika, AN Mbiguino, M Mouallif, A Khattabi, MM Ennaji: Awareness and knowledge regarding of cervical cancer, pap smear screening, and human papillomavirus infection in Gabonese women: BMC Women's Health 2015;15:37.

17. $\mathrm{T}$ Dhendup, $\mathrm{P}$ Tshering. Cervical cancer knowledge and screening behaviours among female university graduates of the year 2012 attending the national graduate orientation program, Bhutan. BMC Women's Health 2014;14:1472-6874.

18. U Ibrahim. Assessment of cervical cancer knowledge, perception, and prevention attitude among female students of reproductive age (16-49) in four tertiary institutions within Bauchi Metropolis. Int J Adv Res Technol 2014;3:2278.

19. V Kulkarni, Darshan BB, A Tandon, B Unnikrishnan, Sriranjani Iyer, A Kukreja, et al. Awareness and practice regarding cervical cancer prevention among female college students of mangalore city. India: Asian J Pharm Clin Res 2015;8:305-7.

20. Y Hong, C Zhang, Xiaoming Li, D Lin, Y Liu. HPV and cervical cancer-related knowledge, Awareness, and testing behaviours in a community sample of female sex workers in China; 2013. Available from: http://www.biomedcentral.com/2014/14712458 13:696. [Last accessed on 01 Mar 2017]. 